DOI: https://doi.org/10.47405/mjssh.v5i8.457

\begin{tabular}{|c|c|}
\hline 4 & Malaysian Journal of Social Sciences and Humanities (MJSSH) \\
\hline $\begin{array}{l}\text { Malaysian Journal of } \\
\text { Social sciences and }\end{array}$ & Volume 5, Issue 8, August 2020 \\
\hline (MJ-SSH) & e-ISSN : 2504-8562 \\
\hline & $\begin{array}{l}\text { Journal home page: } \\
\text { www.msocialsciences.com }\end{array}$ \\
\hline
\end{tabular}

\title{
Pengurusan Pusat Jagaan Kanak-Kanak Berkediaman (Persendirian / NG0) di Negeri Selangor
}

\author{
Syed Lamsah Syed Chear ${ }^{1}$, Said Darkasi¹, Fadliah Darini', Irma Syuryani Jaswir ${ }^{1}$, Noor Izzati Abdul \\ Hamid ${ }^{1}$ \\ 1Fakulti Pendidikan dan Sains Sosial, Universiti Selangor (UNISEL)
}

Correspondence: Syed Lamsah Syed Chear (syedlamsah@unisel.edu.my)

\begin{abstract}
Abstrak
Selangor dianggap sebagai negeri termaju di Malaysia serta menjadi pusat pertumbuhan ekonomi negara. Tanpa diduga Selangor merupakan antara negeri yang menerima jumlah tertinggi bantuan kanak-kanak selepas Sarawak, Sabah, Kelantan dan Johor. Selangor mencatatkan jumlah terbanyak pusat jagaan kanak-kanak berdaftar dan jumlah penghuni tertinggi. Objektif kajian ini adalah untuk meninjau operasi Pusat Jagaan Kanak-Kanak Berkediaman (Persendirian/Swasta/NGO) di negeri Selangor. Data kajian diperolehi melalui lawatan dan pemerhatian di lapangan, temubual berstruktur dengan pengurus institusi dan semakan dokumen. Sebanyak 46 buah institusi telah dilawati dalam tempoh kajian. Bagaimanapun hanya 28 buah institusi yang bersedia terlibat dengan kajian iaitu mewakili $42 \%$ daripada jumlah institusi di seluruh negeri Selangor. Hasil tinjauan menunjukkan bahawa tahap kualiti pengurusan Pusat Jagaan Kanak-Kanak Berkediaman (Persendirian/Swasta/NGO) di negeri Selangor amnya adalah baik kerana mempunyai fasiliti minima yang diperlukan serta diuruskan oleh individu yang berkelayakan. Kajian ini mencadangkan agar agensi-agensi berwajib di peringkat negeri khususnya yang berkaitan dengan perkhidmatan sosial dan kemasyarakatan memberi lebih perhatian terhadap pengoperasian rumah kebajikan kanak-kanak. Ianya penting untuk memastikan kanak-kanak dalam jagaan rumah kebajikan berpeluang membangunkan diri dengan cara yang sama berkualiti seperti kanak-kanak dalam jagaan ibu-bapa agar mereka mampu dan lebih bersedia untuk meneroka kehidupan serta menghadapi cabaran selepas keluar daripada institusi jagaan.
\end{abstract}

Kata kunci: rumah kebajikan kanak-kanak, pengurusan institusi sosial, kesejahteraan sosial

\section{The Management of Children's Welfare Home (Private / NGO) di Selangor}

\begin{abstract}
Selangor is regarded as the most advanced state in Malaysia and plays an important role as the centre of economic growth for the nation. Unfortunately the state of Selangor was among the highers receiver of ministry children's assistance funds behind Sarawak, Sabah, Kelantan and Johor. Selangor recorded the most number of registered children welfare home centre and occupants as compared to other states. The objective of this study is to analyze the operational status of children's welfare home (private/NGO) in the state of Selangor. Data collection include interview with the managers, questionnaires, document review and on-site observations. A total of 46 institutions were visited in the review period. However, only 28 institutions were prepared to be involved with the study representing $42 \%$ of the total institutions throughout the state of Selangor. The finding shows, in general all of the institutions have minimum required facilities and managed by experienced and qualified individuals.
\end{abstract}


This study suggested the state's agencies especially those related to social and communities services to give more attention to the operational status of children's welfare home. It is important to ensure the children's have the opportunity to develop themselves as good as the children in their parents ' custody so that they are able to face challenges ahead after leaving the institution.

Keywords: children's welfare home, managing social institutions, well-being

\section{Pengenalan}

Pelan Pembangunan Pendidikan Malaysia 2013-2025 (PPPM) menyenaraikan lima aspirasi sistem pendidikan iaitu akses, kualiti, ekuiti, perpaduan dan kecekapan (KPM, 2013a). Akses bermaksud setiap kanak-kanak di Malaysia berhak mendapat kesamarataan peluang pendidikan bagi membolehkan mereka mencapai potensi masing-masing manakala ekuiti merujuk kepada sistem pendidikan berprestasi tinggi yang menyediakan pendidikan berkualiti kepada setiap kanak-kanak tanpa mengira kedudukan geografi, jantina dan latar-belakang sosioekonomi. Indikator pencapaian pendidikan di Malaysia ditunjukkan oleh statistik kadar penyertaan murid antara 93.5-95.0 peratus di peringkat rendah dan 79.0-83.0 peratus di peringkat menengah ke sekolah kerajaan dan bantuan kerajaan bagi tempoh lima tahun antara 2013-2017 (KPM, 2017). Dalam tempoh yang sama terdapat peningkatan $25 \%$ jumlah kanak-kanak yang ditempatkan di Pusat Jagaan di seluruh negara iaitu daripada 28,267 pada tahun 2015 kepada 35,491 pada tahun 2016; dan turut dilaporkan terdapat seramai 6,076 kanakkanak adalah penghuni institusi kebajikan seperti Rumah Kanak-Kanak, Asrama Akhlak, Sekolah Tunas Bakti dan sebagainya (JKM, 2016). Situasi ini menimbulkan kebimbangan terhadap keupayaan kerajaan untuk mencapai 50\% pengurangan dalam pencapaian sekolah bandar dan luar-bandar dan mencapai kedudukan dalam kelompok sepertiga teratas dalam pentaksiran antarabangsa seperti seperti Programme for International Student Assessment (PISA) dan Trends in International Mathematics and Science Study (TIMSS) (KPM, 2013b).

Walaupun negara mencatatkan pertumbuhan ekonomi yang baik dari setahun ke setahun, namun terdapat keluarga yang menghadapi kesukaran dan ia memberi kesan kepada kehidupan kanak-kanak dalam keluarga tersebut. Kerajaan pada tahun 2013 menyalurkan sejumlah 327.8 juta Ringgit Malaysia melalui Skim Bantuan Kanak-Kanak (BKK) untuk memberi peluang kepada kanak-kanak yang kurang bernasib baik untuk terus kekal bersama keluarga. Jumlah ini adalah lima kali ganda berbanding 91.9 juta Ringgit Malaysia pada tahun 2008. Jumlah penerima bantuan turut meningkat daripada 37,239 kepada 99,771 orang kanak-kanak dalam tempoh tersebut. Segala bentuk bantuan yang diberikan ini gagal untuk mengubah taraf hidup penerima bantuan iaitu ia tidak dapat memenuhi keperluan asas dan penerima atau keluarga penerima masih rentan kepada situasi ekonomi (UPM, 2017). Pada tahun 2016, seramai 75,479 kanak-kanak menerima skim BKK dengan jumlah peruntukan 246 juta Ringgit Malaysia (JKM, 2016). Walaupun ia sedikit berkurang berbanding 89,712 kanak-kanak dan jumlah peruntukan 279 juta Ringgit Malaysia pada tahun 2014, namun ia tetap memberi bayangan akan kesukaran hidup kanak-kanak dalam kelompok ini. Dari aspek penyertaan sosial, kajian oleh Siti Hajar, Noralina dan Zaiton (2017) menunjukkan tahap kesejahteraan subjektif kanak-kanak miskin di Malaysia masih berada pada tahap sederhana. Senario sebegini menunjukkan masih banyak usaha perlu dilakukan kerajaan sebagai komitmen untuk mematuhi Perkara 28 Konvensyen Kanak-Kanak Sedunia UNESCO iaitu menjadikan pendidikan rendah diwajibkan dan disediakan secara percuma kepada semua (SUHAKAM, 2005). Antara yang disarankan adalah mengubah ukuran garis kemiskinan yang berdasarkan rasional ekonomi kepada pendekatan bersifat multidimensional merangkumkan keupayaan yang kurang atau lemah seperti ketiadaan akses kesihatan, pendidikan, infrastruktur, kebebasan politik dan hak asasi, sumber dan sebagainya (Khalid, 2016).

Ketika ini terdapat 1,853 buah Pusat Jagaan di seluruh negara iaitu 1,257 buah diuruskan oleh persendirian manakala 596 di bawah naungan organisasi bukan kerajaan (JKM, 2016). Pengendalian Pusat Jagaan adalah tertakluk kepada Akta 506 Akta Pusat Jagaan 1993 iaitu suatu akta untuk mengadakan peruntukan bagi pendaftaran, pengawalan, dan pemeriksaan Pusat Jagaan dan bagi perkara yang berkaitan dengannya dibawah tanggungjawab Ketua Pengarah, Jabatan Kebajikan 
Malaysia (JKM). Kajian oleh Jabatan Kebajikan Masyarakat (JKM) bersama beberapa agensi terhadap 402 buah Rumah Kebajikan yang berdaftar di Malaysia mendapati kebanyakkannya gagal memenuhi sebahagian besar daripada komitmen sepertimana terkandung dalam Konvensyen Hak Kanak-Kanak Sedunia UNESCO (Pathmanathan \& Siti Hajar, 2013). Laporan sebegini adalah menyedihkan dan kebimbangan tersebut disuarakan oleh Pengerusi Yayasan Orphancare dan Timbalan Menteri Pembangunan Wanita, Keluarga dan Masyarakat melalui pernyataan bersama bahawa kanak-kanak tidak boleh diasingkan daripada masyarakat kerana kanak-kanak ini akan mengalami kekurangan rangsangan pada usia awal dan lebih cenderung menghadapi masalah sosial, emosi dan psikologi di kemudian hari dan menyukarkan mereka untuk kehidupan yang normal apabila meninggalkan institusi (Harian Metro, 7/12/2016). Isu-isu yang dibangkitkan di atas menjadi pendorong kepada keperluan untuk melakukan kajian ini.

Kajian ini berlingkar kepada isu-isu berkaitan peningkatan bilangan kanak-kanak yang mendapat lindungan institusi jagaan dan kerisauan akan kegagalan pengurusan institusi untuk memenuhi Hak Kanak-Kanak. Kanak-kanak yang menghuni rumah kebajikan kemungkinan tidak menerima peluang pendidikan yang sama berkualiti seperti yang diperoleh oleh kanak-kanak yang tinggal bersama keluarga. Kegagalan pihak institusi mendapat sokongan dan bantuan daripada agensi berwajib akan mendedahkan para penghuni kepada masalah-masalah sosial, emosi dan psikologi sehingga terjadinya insiden-insiden yang tidak diingini. Objektif kajian ini adalah untuk meninjau pengoperasian rumah kebajikan kanak-kanak berkediaman yang dianjurkan oleh badan persendirian, swasta dan pertubuhan bukan kerajaan. Persoalan-persoalan yang ingin dijawab adalah:

i. Bagaimanakah status pendaftaran sesebuah pusat jagaan?

ii. Adakah pengurusan pusat jagaan mencapai tahap kualiti yang diharapkan?

Hasil kajian ini diharap dapat membantu agensi-agensi berkepentingan seperti Jabatan Kebajikan Masyarakat (JKM), Lembaga Pungutan Zakat Negeri (LPZ), Jabatan Pelajaran Negeri (JPN) serta badan amal organisasi bukan kerajaan (NGO) untuk mengetahui dengan lebih terperinci latar belakang operasi rumah kebajikan kanak-kanak bagi tujuan menyelaras perkhidmatan dan bantuan yang dirancang. Ia juga diharap dapat meningkatkan kesedaran di kalangan masyarakat perihal tanggungjawab sosial masing-masing demi manfaat bersama.

\section{Metod Kajian}

Kajian ini memerlukan pengkaji melawat dan berinteraksi mesra dengan pentadbir-pentadbir di Pusat Jagaan (rumah kebajikan kanak-kanak). Ia penting untuk memastikan terma yang digunakan difahami dengan cara yang sama di kalangan para pentadbir yang mempunyai pengalaman dan latarbelakang akademik yang berbeza-beza. Interaksi bersemuka memberi ruang kepada pengkaji untuk meneroka dan menganalisa maklumat-maklumat daripada pelbagai perspektif yang tidak dapat diukur secara kuantiti dan maklumat yang berbeza mungkin diperoleh daripada situasi yang berbeza (Noraini, 2013). Lawatan ke institusi-institusi memberi peluang kepada pengkaji untuk membuat penelitian fenomena dan membina makna daripada perspektif yang dikehendaki. Borang soal-selidik dan senarai semak digunakan untuk catatan temubual dan merekod data.

\section{Kerangka Konseptual Kajian}

Kerangka konseptual kajian dapat dikaitkan kepada beberapa teori seperti Teori Tingkahlaku (Skinner, 1938), Teori Kognitif Sosial (Bandura, 1986) dan Teori Budaya Pembelajaran Sosial (Vygotsky, 1978). Berdasarkan teori tingkahlaku, tindakan-tindakan seseorang individu dikatakan boleh diramal kerana ia dipengaruhi oleh ransangan atau aktiviti-aktiviti yang berlaku di sekeliling mereka. Teori pembelajaran sosial pula menjelaskan bahawa seseorang mempelajari sesuatu akibat daripada interaksi dengan orang sekeliling dan pemerhatiannya terhadap persekitaran. Proses pembelajaran ini dipengaruhi oleh interpretasi seseorang terhadap terhadap persekitaran dan bagaimana mereka percaya serta berfikir mengenainya. Teori pembelajaran budaya sosial memberikan kerangka konsep yang hampir sama iaitu persekitaran sosial mendorong kepada perubahan berterusan terhadap tingkahlaku dan pemikiran seseorang dan ia berbeza antara sesuatu budaya. Pembelajaran ini berlaku dalam tiga kaedah iaitu 
DOI: https://doi.org/10.47405/mjssh.v5i8.457

meniru (imitative learning), diarahkan (instruction to self-learning) dan pembelajaran bersama (collaborative learning). Berdasarkan kepada gabungan ketiga-tiga teori di atas, pengkaji membangunkan kerangka konsep kajian bahawa pembangunan diri dan kesediaan kanak-kanak untuk hidup di luar institusi jagaan adalah dipengaruhi oleh latarbelakang kehidupan mereka serta persekitaran yang dilalui di rumah kebajikan. Rajah 1 menunjukkan bahawa bahawa potensi dan pembangunan diri kanak-kanak dipengaruhi oleh pengalaman yang ditempuhi dalam kehidupan seharian di rumah kebajikan serta kemampuan mereka untuk membuat interpretasi positif terhadap pengalaman yang mereka lalui itu.

Rajah1: Kerangka konseptual kajian untuk meramal potensi pembangunan diri kanak-kanak

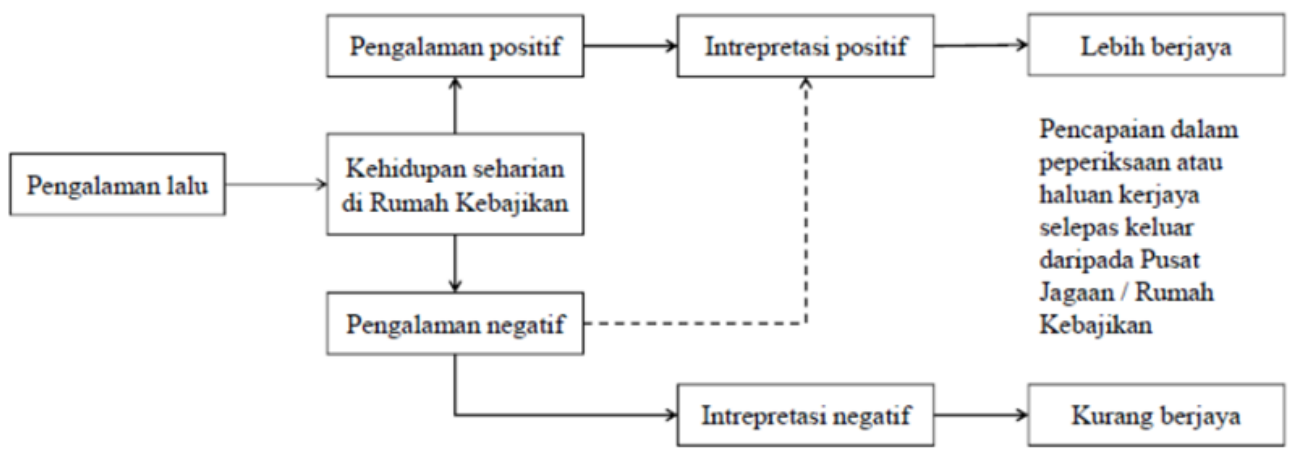

\section{Populasi dan Sampel Kajian}

Lokasi kajian terhad kepada Pusat Jagaan Kanak-Kanak Berkediaman (Swasta/NGO) di negeri Selangor. Secara operasional ia merujuk kepada mana-mana institusi berdaftar yang dimiliki oleh orang perseorangan, syarikat atau organisasi bukan kerajaan yang menyediakan perkhidmatan jagaan sepenuh masa secara berbayar atau khidmat sosial.

Jadual 1: Statistik Pusat Jagaan Kanak-Kanak Berdaftar di Negeri Selangor 2019

\begin{tabular}{lccccc}
\hline Daerah & \multicolumn{3}{c}{ Bilangan Institusi Berdasarkan Kategori } & Jumlah \\
\cline { 2 - 5 } & $\begin{array}{c}\text { Harian } \\
\text { (Swasta) }\end{array}$ & $\begin{array}{c}\text { Harian } \\
\text { (NGO) }\end{array}$ & $\begin{array}{c}\text { Berkediaman } \\
\text { (NGO) }\end{array}$ & $\begin{array}{c}\text { Berkediaman } \\
\text { (Swasta) }\end{array}$ & \\
\hline Petaling & 9 & 1 & 13 & 5 & 28 \\
Subang Jaya & 68 & 3 & 3 & 2 & 76 \\
Shah Alam & 17 & 0 & 3 & 1 & 20 \\
Hulu Selangor & 2 & 0 & 3 & 1 & 6 \\
Hulu Langat & 20 & 0 & 8 & 2 & 30 \\
Sepang & 21 & 0 & 1 & 2 & 24 \\
Sabak Bernam & 1 & 0 & 2 & 0 & 3 \\
Kuala Selangor & 2 & 0 & 0 & 0 & 2 \\
Kuala Langat & 4 & 0 & 1 & 0 & 5 \\
Klang & 47 & 0 & 11 & 2 & 67 \\
Gombak & 34 & 1 & 5 & 2 & 42 \\
& 225 & 5 & 50 & 17 & 297 \\
\hline
\end{tabular}

Sumber: Laman sesawang JKM pada 24 Februari 2019

Di seluruh negara terdapat 1,853 buah Pusat Jagaan dalam kategori ini iaitu 1,257 buah diuruskan oleh persendirian/swasta manakala 596 di bawah naungan organisasi bukan kerajaan. Daripada jumlah tersebut hanya 805 buah berstatus berkediaman. Selangor merupakan negeri yang mempunyai jumlah tertinggi bilangan institusi, jumlah penjaga dan penghuni (JKM, 2016). Kebanyakan terdapat di daerah Petaling, Kuala Langat dan Hulu Langat seperti di Jadual 1. Jumlah Pusat Jagaan Berkediaman yang 
DOI: https://doi.org/10.47405/mjssh.v5i8.457

termasuk dalam skop kajian adalah 67 buah iaitu 50 milik NGO dan 17 adalah rumah kebajikan yang diuruskan oleh individu atau agensi swasta. Persampelan dibuat untuk menjimatkan kos penyelidikan melalui pengurangan kos perjalanan, percetakan instrumen penyelidikan, khidmat pembantu penyelidik dan sebagainya (Noraini, 2013). Menurut Fraenkel dan Wallen (2006), persampelan membolehkan penyelidik menjimatkan masa dan hasil kajian yang diperoleh daripada sampel yang dipilih mengikut prosedur saintifik boleh digeneralisasikan terhadap populasi.

\section{Kaedah Pengumpulan Data}

Senarai Pusat Jagaan diperolehi daripada Jabatan Kebajikan Masyarakat (JKM), Negeri Selangor. Setelah mendapat surat sokongan daripada Pengarah JKM Negeri Selangor, pengkaji menghubungi pihak institusi untuk menjelaskan objektif kajian, memohon persetujuan dan menetapkan tarikh lawatan. Pengkaji memilih sesebuah institusi mengikut persampelan tujuan iaitu berdasarkan pengetahuan penyelidik terhadap sesebuah institusi yang dijangka dapat memberikan maklumat mewakili keseluruhan rumah kebajikan yang berbeza-beza latarbelakang. Pemilihan responden yang tepat dapat memberikan data yang lebih berkualiti sama seperti pemilihan rawak serta dapat digunakan secara berkesan untuk kedua-dua penyelidikan kuantitatif dan kualitatif (Tongco, 2007). Kumpulan pengkaji membuat penyelidikan awal berkaitan institusi melalui media internet dan sebagai untuk mengetahui serba sedikit latarbelakang institusi. Ia penting untuk mengelakkan timbulnya perkara tidak diingini atau menyentuh sensitiviti semasa lawatan sepertimana disyorkan oleh Adhabi dan Anozie (2017). Temubual, semakan dokumen dan pemerhatian dilakukan di institusi kajian dan melibatkan individu berjawatan tertinggi yang terlibat membuat dasar di institusi. Lawatan ulangan dilakukan untuk mendapat maklumat tambahan apabila perlu. Kajian rintis telah dilakukan di 4 buah institusi setahun sebelum kajian sebenar dilakukan untuk membantu kumpulan penyelidik memahami latarbelakang sesebuah pusat jagaan bagi menyediakan borang soal-selidik dan dokumentasi yang diperlukan.

Pengumpulan data menggunakan tiga borang. Borang A mencatatkan informasi latarbelakang institusi dan para pentadbir. Borang $\mathrm{B}$ adalah soal-selidik berkaitan aspek perancangan dan pengurusan program sokongan akademik di institusi mencakupi 10 aspek iaitu visi dan misi, peranan pengurus, sokongan agensi awam, fasiliti yang disediakan, pengurusan kewangan, kelayakan pengasuh/penjaga, personaliti penghuni, penglibatan ibu-bapa dan komuniti setempat, kerjasama dengan pihak sekolah dan hubungan strategik. Borang $\mathrm{C}$ adalah soalan-soalan temubual berkaitan aspirasi para pentadbir terhadap halatuju institusi.

\section{Analisis Data}

Maklumat latarbelakang institusi dan pentadbir dilaporkan secara perbandingan antara institusiinstitusi. Proses triangulasi atau menentusah data yang dikumpul daripada temubual dan pemerhatian di institusi disemak melalui temubual dengan Jabatan Kebajikan Masyarakat (JKM), Negeri Selangor dan semakan dokumen berkaitan. Pelaporan skop kemahiran dan kesediaan para pentadbir di institusi untuk merancang dan mengurus program sokongan akademik adalah berdasarkan statistik deskriptif iaitu data diringkaskan dengan menggunakan ukuran kecenderungan memusat iaitu mengambil nilai kekerapan (frekuensi) dan peratusan kekerapan (\%).

\section{Dapatan Kajian dan Perbincangan}

\section{Profil Institusi}

Dalam tempoh kajian pengkaji telah melawati 46 buah Pusat Jagaan Berkediaman (Persendirian/NGO) meliputi daerah Gombak, Hulu Langat, Hulu Selangor, Kuala Langat, Sabak Bernam, Sepang, Shah Alam dan Subang Jaya mengikut senarai berdaftar dengan Jabatan Kebajikan Masyarakat Negeri Selangor (JKM Selangor). Dua daerah dikecualikan iaitu Petaling dan Klang yang mempunyai 31 buah institusi disebabkan tempoh kajian yang singkat serta faktor-faktor strategik lain. Bagaimanapun hanya 
DOI: https://doi.org/10.47405/mjssh.v5i8.457

28 buah institusi bersedia untuk terlibat dengan kajian manakala selebihnya menolak. Maklumat umum latarbelakang institusi yang terlibat dengan kajian adalah seperti di Jadual 2.

Jadual 2: Latarbelakang Pusat Jagaan Kanak-Kanak Berkediaman di Negeri Selangor

\begin{tabular}{lc}
\hline Latar Belang Pusat Jagaan & Bilangan \\
\hline Tempoh Beroperasi & 1 \\
$\leq 5$ tahun & 10 \\
$\leq 10$ tahun & 14 \\
$>10$ tahun & \\
Jenis Premis & 10 \\
$\quad$ Rumah Teres & 0 \\
Lot kedai & 8 \\
Bangunan Sebuah & 7 \\
Kompleks & \\
Pemilikan & 10 \\
Sendiri & 7 \\
Sewaan & 5 \\
Wakaf & 3 \\
Lain-lain & \\
Bilangan Staf & 7 \\
$\leq 5$ & 11 \\
$\leq 10$ & 2 \\
$>10$ & 6 \\
Lain-lain & \\
Bilangan Penghuni & 7 \\
$\leq 25$ orang & 7 \\
$\leq 50$ orang & 6 \\
$\leq 100$ orang & 2 \\
$>100$ orang & \\
\hline
\end{tabular}

Amnya lokasi institusi-institusi adalah di bandar dan pinggir bandar serta berhampiran dengan perumahan atau berada dalam kawasan kediaman. Sebilangan besar institusi telah beroperasi sejak 10 hingga 15 tahun tahun lalu. Rumah Bakti Dato' Harun yang diuruskan oleh Pertubuhan Pendidikan Anak Yatim Selangor merupakan institusi terawal ditubuhkan iaitu pada tahun 1976. Institusi lain antaranya adalah Asrama Kebajikan Anak-Anak Yatim Miskin, Sekendi (1985), Rumah Anak Yatim Islam dan Miskin Daerah Sabak Bernam (1985) dan Asrama Damai Rumah Anak-Anak Yatim, Kuang (1989). Kebanyakan institusi terdapat di kawasan kediaman (rumah teres) dengan kemudahan yang terhad. Institusi yang lebih besar dan dianggap lebih sempurna didirikan dalam bentuk bangunan sebuah atau kompleks. Antaranya adalah Asrama Yayasan Basmi Kemiskinan (YBK), Serendah; Rumah Kasih Harmoni, Paya Jaras; Pusat Jagaan Pertubuhan Kebajikan \& Pendidikan Nur Kasih, Kapar; dan Pusat Jagaan Pertubuhan Rumah Anak Yatim Berkat Kasih, Klang. Status pemunyaan premis sebilangan institusi sukar untuk ditentukan kerana terdapat pertindihan antara milik sendiri, sewaan dan wakaf.

Bilangan staf amnya berkait dengan jenis premis dan jumlah penghuni sesebuah pusat jagaan. Asrama Damai Rumah Anak-Anak Yatim, Kuang dan Pusat Jagaan Rumah Amal Raudhatul Jannah, Banting mempunyai bilangan staf paling ramai iaitu 19 dan 14 orang tetapi sebahagiannya adalah sukarelawan tetap dan ada juga antara mereka merupakan penghuni dewasa di pusat jagaan berkenaan. Jumlah penghuni berdaftar di 25 buah pusat jagaan yang dilawati adalah seramai 1,151 orang kanak-kanak. Hampir kesemua kanak-kanak berpeluang mengikuti persekolahan kecuali 30 orang (2.6\%) disebabkan pelbagai faktor. Pusat Jagaan yang mempunyai jumlah penghuni tertinggi adalah Pusat Jagaan Persatuan Rumah Kebajikan Rita, Jalan Kapar (152), Pusat Jagaan Asrama Damai Rumah Anak-Anak Yatim, Kuang (127), Rumah Kasih Harmoni, Paya Jaras (91), Pusat Jagaan Cahaya Kasih Bestari, 
Kampung Melayu, Subang (91), dan Pusat Jagaan Pertubuhan Kebajikan \& Pendidikan Nur Kasih, Klang (80).

Status penubuhan institusi-institusi didapati berbeza dengan rekod pendaftaran di Jabatan Kebajikan Masyarakat (JKM), Selangor. Tiada alasan jelas diberikan oleh institusi-institusi yang tidak mahu terlibat dengan kajian ini. Beberapa institusi didapati telah tamat tempoh kelulusan dan tidak lagi beroperasi. Terdapat juga institusi yang gagal untuk dihubungi atau tidak berada di premis yang didaftarkan. Sebuah institusi yang dilawati di Hulu Selangor didapati menjalankan aktiviti berbeza iaitu sebagai pusat pemulihan dan rawatan akhlak. Lokasi institusi-institusi kebanyakannya mudah dihubungi dan mempunyai akses kepada perkhidmatan awam seperti sekolah, balai polis, bomba serta jabatan kerajaan lain. Keseluruhannya pusat-pusat jagaan yang dilawati didapati mempunyai struktur pengurusan yang baik serta persekitaran fizikal yang memuaskan untuk memberikan perkhidmatan jagaan dan sosial kepada para penghuni. Beberapa institusi seperti Rumah Bakti Dato' Harun, Asrama Yayasan Basmi Kemiskinan (YBK), Serendah dan Rumah Amal Cahaya Tengku Ampuan Rahimah (RACTAR) dianggap sangat baik. Institusi lain seperti Pusat Jagaan Rumah Amal Raudhatul Jannah, Banting; Persatuan Rumah Kebajikan Rita, Kapar; Rumah Kasih Harmoni, Paya Jaras; Pusat Jagaan Pertubuhan Kebajikan Ukhuwah Anak Yatim Islam dan Miskin Daerah Sabak Bernam; dan Asrama Damai Rumah Anak-Anak Yatim, Kuang turut menyediakan perkhidmatan sosial yang baik kepada penghuni.

\section{Pengurusan Pusat Jagaan Kanak-Kanak Berkediaman}

Akta Pusat Jagaan 1993 (Akta 506) mewajibkan pengendali untuk memastikan adanya kakitangan yang mencukupi dan berkelayakan; pusat jagaan dilengkapkan dan disenggarakan dengan baik bagi perkhidmatan jagaan, kawalan, penyeliaan, layanan dan latihan; termasuk menyediakan kemudahan rawatan dan rekreasi. Hasil tinjauan mendapati latarbelakang pengurusan Pusat Jagaan Kanak-Kanak Berkediaman (Swasta/NGO) di Selangor adalah baik. Sebilangan besar daripada pengendali atau pengurus $(65.4 \%)$ mempunyai kelulusan Diploma dan Sarjana Muda dan separuh daripada jumlah kakitangan $(50 \%)$ turut memiliki kelayakan akademik yang sama. Seorang daripada Pengurus didapati berkelulusan ijazah sarjana dan seorang staf memiliki ijazah perubatan (MBBS). Kelayakan lain adalah Sijil Tinggi Persekolahan Malaysia (STPM), Sijil Pelajaran Malaysia (SPM) dan setara.

Tahap pengalaman dan kemahiran pengendali atau pengurus berbeza-beza antara institusi. Sebilangan mereka bekerja di pusat jagaan secara sukarela atau separuh masa. Tiada satu kriteria tetap untuk menentukan tahap kemahiran seseorang pengendali atau pengurus. Ini kerana persekitaran di sesebuah pusat jagaan adalah berbeza-beza. Amnya seseorang yang telah lama mengurus sesebuah pusat jagaan yang mempunyai jumlah penghuni yang ramai dianggap lebih berpengalaman dan berkemahiran. Antara institusi yang telah beroperasi lebih daripada sepuluh tahun, mempunyai jumlah penghuni yang ramai dan kompleks premis adalah Asrama Damai Rumah Anak-Anak Yatim, Kuang; Persatuan Rumah Kebajikan Rita, Kapar; Rumah Bakti Dato' Haron, Ampang; Yayasan Sunbeams Home, Kuala Lumpur; Pertubuhan Kebajikan Ukhuwah Anak Yatim Islam dan Miskin Daerah Sabak Bernam, Sungai Besar; Rumah Kasih Harmoni, Paya Jaras; dan Pertubuhan Kebajikan \& Pendidikan Nur Kasih, Klang. Kebanyakan daripada pusat jagaan mempunyai kalangan kakitangan yang berkelulusan Diploma atau Sarjana Muda (13 buah/50\%). Hal ini membayangkan akan kualiti perkhidmatan yang disediakan serta kesedaran tentang kepentingan pendidikan di sesebuah pusat jagaan. Maklumat latarbelakang akademik dan pengalaman kakitangan di pusat jagaan ditunjukkan di Jadual 3.

Jadual 3: Maklumat pengurusan Pusat Jagaan Kanak-Kanak di Negeri Selangor

\begin{tabular}{lccc}
\hline \multicolumn{4}{c}{ Bilangan dan Peratusan Pengurus bagi Institutsi } \\
\hline Makluman Pengurusan & $\begin{array}{c}\text { Setara } \\
\text { (Bilangan) }\end{array}$ & $\begin{array}{c}\text { Sederhana } \\
\text { (Bilangan) }\end{array}$ & $\begin{array}{c}\text { Tinggi } \\
\text { (Bilangan) }\end{array}$ \\
\hline Akademik Pengendali & 8 & 17 & 1 \\
Pengalaman Pengendali & 8 & 9 & 9 \\
Akademik Staf & 11 & 13 & 2 \\
\hline
\end{tabular}


DOI: https://doi.org/10.47405/mjssh.v5i8.457

Persekitaran berkualiti sistem sokongan kebajikan diketahui memberi impak positif terhadap kanakkanak iaitu daripada aspek keupayaan kognitif, berbahasa, kawalan emosi dan tingkahlaku sosial (Harden \& Whittaker, 2011; Stahmer, 2009). Di peringkat tempatan, kajian oleh Awang et al. (2004) mendapati masalah ketara yang dihadapi oleh kanak-kanak di rumah kebajikan adalah yang berkaitan dengan pendidikan dan masa hadapan. Ketiadaan ibu bapa atau keluarga menyukarkan mereka untuk menerima bimbingan dan galakan yang diperlukan. Kanak-kanak didapati terdedah kepada pelbagai penyakit (Muhammad Zayyid et al., 2010). Kajian ini mendapati kebanyakan pusat jagaan mempunyai kakitangan yang berkelulusan dan ia diharap dapat membantu dalam menyediakan program sokongan yang lebih berkualiti yang memberi manfaat kepada penghuni baik dari aspek kognitif, mental, fizikal dan seumpamanya.

\section{Fasiliti di Institusi}

Terdapat tiga jenis premis pusat jagaan iaitu rumah teres, bangunan sebuah dan kompleks. Pusat jagaan yang ditubuhkan sebagai kompleks bangunan amnya mempunyai fasiliti yang lebih baik berbanding rumah teres. Semua pusat jagaan yang dilawati mempunyai pejabat untuk menerima tetamu. Fasiliti lain yang terdapat di pusat jagaan adalah bilik pengurus $(85 \%)$, bilik belajar $(85 \%)$, perpustakaan (74\%), bilik kakitangan (74\%), CCTV (70\%), gelanggang permainan (67\%) dan bilik kaunseling (63\%). Gambaran sebegini membayangkan akan perkhidmatan jagaan yang diberikan di kebanyakan pusat jagaan kanak-kanak berkediaman di Selangor adalah baik dan mampu memberi jaminan terhadap perkembangan positif kanak-kanak di pusat jagaan. Antara premis yang menyediakan kemudahan serba lengkap adalah kompleks Rumah Bakti Dato' Harun dan Asrama Damai YBK Serendah yang memiliki asrama bertingkat, perpustakaan, surau, beberapa jenis gelanggang permainan dan perkhidmatan pengangkutan bas dan van untuk kegunaan penghuni. Pusat jagaan seperti Rumah Amal Cahaya Tengku Ampuan Rahimah (RACTAR) dan Persatuan Rumah Kebajikan Rita mempunyai bengkel kemahiran untuk memberi latihan kepada para penghuni. Fasiliti seperti kamera litar tertutup (CCTV) memberi jaminan akan kawalan keselamatan manakala bilik kaunseling yang disediakan dapat dikaitkan kepada kualiti program kaunseling dan motivasi di sesebuah pusat jagaan. Senarai fasiliti yang terdapat di pusat jagaan yang dilawati adalah seperti di Jadual 4.

Jadual 4: Fasiliti yang disediakan di Pusat Jagaan Kanak-Kanak di Selangor

\begin{tabular}{lcc}
\hline Jenis Fasiliti & \multicolumn{2}{c}{ Kuantiti dan Peratusan } \\
\cline { 2 - 3 } & Bilangan & $\%$ \\
\hline Pejabat & 27 & 100.0 \\
Bilik Pengurus & 23 & 85.2 \\
Bilik Staf & 20 & 74.1 \\
Bilik Mesyuarat & 16 & 59.5 \\
Bilik Kaunseling & 17 & 63.0 \\
Bilik Sakit & 8 & 30.0 \\
Surau & 20 & 74.1 \\
Bilik Belajar & 23 & 85.2 \\
Perpustakaan & 20 & 74.1 \\
Dewan Makan & 26 & 96.3 \\
Pos Pengawal & 12 & 44.5 \\
CCTV & 19 & 70.4 \\
Gelanggang & 19 & 66 \\
Lain-lain Fasiliti & - & - \\
\hline
\end{tabular}

Lim et al. (2013) dalam kajian terhadap pengurusan fasiliti di rumah kebajikan orang tua mendapati keadaannya tidak memuaskan. Kumpulan pengkaji telah membangunkan kerangka Audit Pengurusan Fasiliti Penjagaan Sosial (SCFMA) supaya institusi-institusi ini dapat memberikan perkhidmatan yang lebih baik. Dapatan kajian oleh Nalasami et al. (2015) bahawa agensi kerajaan yang berwajib gagal memastikan rumah kebajikan (pusat jagaan) mematuhi Konvensyen Hak Kanak-Kanak (CRC) adalah mendukacitakan. 


\section{Sumber dan Persekitaran}

Laporan kewangan merupakan perkara sulit dan dilindungi dalam sesebuah organisasi. Dapatan kajian ini adalah secara ringkas dan tidak menyeluruh kerana pusat-pusat yang terlibat agak keberatan untuk mendedahkannya dan pengkaji juga tidak mendesak kerana ia bukan objektif utama kajian ini. Pengkaji lebih mengutamakan hubungan mesra dan cuba mengekalkan kepercayaan dengan pengurusan institusi pusat jagaan. Rekod sumber kewangan dan perbelanjaan operasi pusat jagaan yang dilawati adalah seperti di Jadual 5. Hanya sebilangan kecil pusat jagaan mengenakan yuran. Sebuah pusat jagaan di Hulu Selangor yang menyediakan perkhidmatan rawatan dan pemulihan mengenakan yuran RM600 sebulan tetapi memaklumkan waris-waris hanya membayar di permulaan sahaja. Institusi terpaksa bergantung kepada sumber lain untuk menampung kos operasi yang menjangkau RM150,000.00 setahun. Perbelanjaan mengurus sesebuah pusat jagaan amnya berkadar dengan jumlah penghuni dan jenis premis institusi. Kos operasi pusat jagaan di premis kompleks yang mempunyai ramai penghuni memerlukan kos yang lebih besar berbanding di rumah teres. Pusat jagaan yang menerima sumbangan, derma atau seumpamanya melebihi RM10,000 sebulan adalah Rumah Bakti Dato' Haron, Pusat Jagaan Pertubuhan Rahoma Darul Fakir Malaysia, Pusat Jagaan Pertubuhan Kebajikan Ehsan Ash-Shakur, Pusat Jagaan Rumah Amal Raudhatul Jannah, Rumah Aman Shah Alam, Asrama Damai Yayasan Basmi Kemiskinan (YBK) dan Pusat Jagaan Yayasan Sunbeams Home. Jumlah ini bukanlah jumlah yang besar setelah mengambilkira bilangan penghuni di setiap pusat jagaan berkenaan. Institusi yang sama memerlukan perbelanjaan yang lebih tinggi untuk penggajian, kos utiliti, penyediaan makanan dan penganjuran aktiviti-aktiviti di pusat jagaan masing-masing.

Kajian terdahulu yang dilakukan oleh Sy Ariffin (2013) terhadap tahap pengurusan rumah kebajikan di daerah Gombak, Selangor mendapati tahap pengurusan institusi-institusi adalah lemah dan institusi juga tidak mendapat sokongan dan bantuan sewajarnya daripada agensi kerajaan. Walaupun operasi institusi-institusi bersifat khidmat sosial dan tidak bermatlamatkan perniagaan, namun status institusi yang tidak berdaftar dengan agensi yang berkaitan seperti Jabatan Kebajikan Masyarakat (JKM), menyukarkan pihak kerajaan untuk menyalurkan bantuan yang diharapkan. Sungguhpun begitu pihak kerajaan, agensi bukan kerajaan dan pertubuhan-pertubuhan tetap disaran memberi lebih perhatian dan sumbangan kepada rumah-rumah kebajikan (Ghani et al., 2016; Tan, 2017).

Jadual 5: Perbandingan sumber kewangan dan perbelanjaan bagi tujuan mengurus operasi

\begin{tabular}{lcc}
\hline Perbandingan Sumber Kewangan & $\begin{array}{c}\text { Bilangan Pusat } \\
\text { Jagaan }\end{array}$ & $\begin{array}{c}\text { Peratusan } \\
(\%)\end{array}$ \\
\hline Dapatan Derma & & \\
RM1,001-5,000 & 8 & $44.5 \%$ \\
RM5,001-10,000 & 3 & $16.7 \%$ \\
RM10,000++ & 7 & $38.8 \%$ \\
Penggajian & 6 & $33.3 \%$ \\
RM1,001-5,000 & 6 & $33.3 \%$ \\
RM5,001-10,000 & 6 & $33.3 \%$ \\
RM10,000++ & & \\
Bil Utiliti & 4 & $21.0 \%$ \\
RM500-1,000 & 4 & $21.0 \%$ \\
RM1,001-5,000 & 11 & $58.0 \%$ \\
RM5,000++ & & \\
Barang Daput & 11 & $58.0 \%$ \\
RM1.001-5,000 & 4 & $21.0 \%$ \\
RM5,001-10,000 & 4 & $21.0 \%$ \\
RM10,000++ & & \\
Kos Aktiviti & 10 & $58.8 \%$ \\
RM1,001-3,000 & 1 & $5.88 \%$ \\
RM3,001-5,000 & 6 & $35.4 \%$ \\
RM5,000++ & & \\
\hline
\end{tabular}




\begin{tabular}{lll}
\hline Lain-lain Perbelanjaan & & \\
RM1,001-3,000 & 7 & $41.1 \%$ \\
RM3,001-5,000 & 4 & $23.5 \%$ \\
RM5,000++ & 6 & $35.4 \%$ \\
\hline
\end{tabular}

\section{Kesimpulan dan Implikasi Kajian}

Status pengurusan Pusat Jagaan Kanak-Kanak Berkediaman (Persendirian/NGO) di negeri Selangor amnya adalah baik kerana mempunyai fasiliti minima yang diperlukan dan diuruskan oleh individu yang berkelayakan. Namun, keperluan pendaftaran sesebuah institusi perlu dipantau daripada semasa ke semasa. Beberapa institusi didapati telah tamat sahlaku pendaftaran dan tidak lagi beroperasi. Ini membayangkan kesukaran hidup dan suasana buruk dalam masyarakat sekiranya kanak-kanak yang menghuni pusat jagaan berkenaan terpaksa keluar tanpa hala tuju. Dapatan kajian ini dapat digunakan oleh agensi berwajib di peringkat negeri untuk merangka program bantuan dan sokongan yang diperlukan. Antaranya adalah menyediakan program latihan kemahiran kepada kakitangan pusat jagaan termasuk para sukarelawan berkaitan ilmu perkembangan kanak-kanak, sosiologi masyarakat, perundangan berkaitan dan seumpamanya. Satu sukatan standard boleh disediakan untuk menyelaras sumbangan daripada syarikat-syarikat swasta terutamanya pada musim-musim perayaan. Institusi latihan dan pendidikan kerajaan negeri perlu memikul tanggungjawab untuk berkolaborasi dengan pusat jagaan untuk pelaksanaan program khidmat sosial (CSR) seperti menganjurkan program sokongan akademik dan haluan kerjaya kepada para penghuni iaitu kanak-kanak di pusat jagaan.

\section{Penghargaan}

Kajian ini dibiayai oleh Geran Penyelidikan Kerajaan Negeri Selangor (GPNS) melalui Universiti Selangor (UNISEL) yang diluluskan bagi tempoh 12 bulan antara November 2018 sehingga November 2019 [No. Geran: UNISEL/CRIL/600/12/18(175)]. Kajian ini turut melibatkan pelajar program Sarjana Muda Pendidikan (Kepujian) (Pendidikan Awal Kanak-Kanak), Universiti Selangor daripada aspek pengumpulan data dan penganjuran pelbagai bentuk program khidmat sosial bersama para penghuni di institusi-institusi terlibat.

\section{Rujukan}

Adhabi, E., \& Anozie, C.B. (2017). Literature review for the type of interview in qualitative research. International Journal of Education, 9(3), 86-97. doi:10.5296/ije.v9i3.11483

Awang, A., Sayuti, R., Jamaluddin, Z., \& Chong, C. C. (2004). Simposium kebangsaan kebajikan kanak-kanak 2004. Kepentingan terbaik kanak-kanak: Isu \& cabaran. Permasalahan anak yatim di Institusi Kebajikan Anak Yatim, 11. Muat-turun daripada https://www.mendeley.com/catalogue/simposium-kebangsaan-kebajikan-kanakkanak-2004kepentingan-terbaik-kanakkanak-isu-cabaran/

Bandura, A. (1986). Social foundation of thought and action: A social cognitive theory. Englewood Cliffs, NJ: Prentice Hall. Di dalam Zhou, M., \& Brown, D. (2015). Educational learning theories. Chapter 3. A. Bandura: Social cognitive theory. Education Open Textbooks.

Fraenkel, J.R., \& Wallen, E.W. (2006). How to design and evaluate research in education. Boston, MA: McGraw Hill. Dalam Idris, N. (2013). Penyelidikan dalam pendidikan (Edisi kedua). Kuala Lumpur: McGraw Hill Education.

Ghani, N. A., Noordin, N., Zulkifli, N. I., Abdullah, B., \& Ghazalli, F. S. M. (2016). Social support for the elderly at darul hanan nursing home, Penang, Malaysia. Man in India, 96(12), 5209-5228.

Harden, B. J., \& Whittaker, J. V. (2011). The early home environment and developmental outcomes for young children in the child welfare system. Children and Youth Services Review, 33(8), 13921403. https://doi.org/10.1016/j.childyouth.2011.04.009

Jabatan Kebajikan Masyarakat (2016). Laporan statistik Jabatan Kebajikan Masyarakat. Muat-turun daripada http://www.jkm.gov.my/ 
Kementerian Pendidikan Malaysia (2013a). Pelan pembangunan pendidikan Malaysia 2013-2025. Peringkat prasekolah hingga lepasan menengah. Putrajaya: Kementerian Pendidikan Malaysia. Muat-turun daripada https://www.moe.gov.my/muat-turun/penerbitan-dan-jurnal/1818-pelanpembangunan-pendidikan-2013-2025/file

Kementerian Pendidikan Malaysia (2013b). Ringkasan eksekutif. Pelan pembangunan pendidikan Malaysia 2013-2025. Peringkat prasekolah hingga lepasan menengah. Putrajaya: Kementerian Pendidikan Malaysia.

Kementerian Pendidikan Malaysia (2017). Perangkaan pendidikan Malaysia. Putrajaya: Bahagian Perancangan dan Penyelidikan Dasar Pendidikan, Kementerian Pendidikan Malaysia.

Khalid, K.A.T (2016). Dilemma kemiskinan: Falsafah, budaya dan strategi. Akademika, 86(2). https://doi.org/10.17576/akad-2016-8602-05

Lim, W., Xin, W., Sulaiman, N., \& Baldry, D. (2013). A conceptual framework for understanding the social care facilities management audit (SCFMA) at the residential care home for the elderly (RCHfE) in Malaysia. 2nd International Conference on Management, Economics and Finance (2nd Icmef 2013), (October), 112-140.

Muhammad Zayyid, M., Saidatul Saadah, R., Adil, A. R., Rohela, M., \& Jamaiah, I. (2010). Prevalence of scabies and head lice among children in a welfare home in Pulau Pinang, Malaysia. Tropical Biomedicine, 27(3), 442-446.

Nalasami, P. R., Bakar, S. H. A., Yusoff, J. Z., Wahab, H. A., Omar, N., \& Islam, M. R. (2015). Implementation of Child Rights in the Children's Homes in Malaysia. Asian Social Work and Policy Review, 9(3), 232-244. https://doi.org/10.1111/aswp.12061

Noraini, I.(2013). Penyelidikan dalam pendidikan (Edisi kedua). Kuala Lumpur: McGraw Hill Education.

Pathmanathan, R. N. \& Siti Hajar, A.B. (2013). Hak kanak-kanak dalam jagaan institusi awam. Kuala Lumpur: Penerbit Universiti Malaya.

Siti Hajar, A.B., Noralina, O., \& Zaiton, A. (2017). Penyertaan sosial dan indeks kesejahteraan sosial subjektif kanak-kanak miskin di Malaysia. Akademika, 87(2), 105-118. https://doi.org/10.17576/akad-2017-8702-08

Skinner, B.F. (1974). About behaviorism (1st ed.). New York: Random House. Di dalam Zhou, M., \& Brown, D. (2015). Educational learning theories. Chapter 1. Behaviorism B. F. Skinner: Response approach toward learning. Education Open Textbooks.

Stahmer, A. C., Hurlburt, M., Horwitz, S. M. C., Landsverk, J., Zhang, J., \& Leslie, L. K. (2009). Associations between intensity of child welfare involvement and child development among young children in child welfare. Child Abuse and Neglect, 33(9), 598-611. https://doi.org/10.1016/j.chiabu.2008.07.008

Sy. Ariffin, Sy. (2013). Orphanage welfare and care centre as integration with community. Arts and Design Studies, 13(n/a), 31-37.

Tan, S. H. (2017). Assessing the needs of caregivers of children with disabilities in Penang, Malaysia. Health and Social Care in the Community, 25(2), 447-457. https://doi.org/10.1111/hsc. 12325

Tongco, M.D.C. (2007). Purposive Sampling as a tool for informant selection. Ethnobotany Research \& Applications, 5, 47-158.

Universiti Putra Malaysia (2017). Laporan akhir. Kajian keberkesanan bantuan kewangan Jabatan Kebajikan Masyarakat, Kementerian Pembangunan Wanita, Keluarga dan Masyarakat. UPM Consultancy \& Services Sdn bhd (A subsidiary of UPM Holdings).

Vygotsky, L. S. (1978). Mind in society. Cambridge, MA: Harvard University Press. Di dalam Zhou, M., \& Brown, D. (2015). Educational learning theories. Chapter 4. Vygotsky: Social cultural learning. Education Open Textbooks. 